\title{
外科矯正治療の術後成績と患者の 満足度の関連性について
}

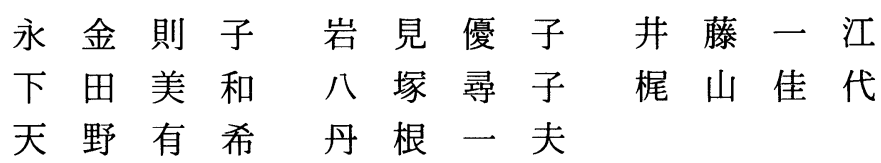

Patient's Recognition of Improvement in Facial Profile due to Orthognathic Surgery

\author{
Noriko NAGAKANE, Yuko IWAMI-MORIMOTO, KazUe ITO, \\ Miwa SHIMODA, HiRoKo YATSUZUKA, KaYo KAJIYAMA, \\ YUKI AMANO and KAZUO TANNE
}

\begin{abstract}
This study was designed to investigate the patient's recognition of changes in facial profile due to orthognathic surgery. The results of questionnaires were summarized and analyzed in relation to cephalometric data.

The subjects consisted of forty-three posttreatment patients ( 13 males and 30 females) with mandibular prognathism,, who had undergone orthognathic surgery at Hiroshima University Dental Hospital. In this study, patient's recognition of improvement in facial profile was summarized in relation to morphologic changes associated with orthognathic surgery by means of Spearman's correlation analysis.

The results were as follows:

1. Before treatment, eighty-eight percent of patients were anxious about disharmony of the facial profiles, and the degree of anxiousness was severe in half of them. As for facial areas, the lower lip and chin were their greatest concern.

2. After treatment, eighty-four percent of patients recognized improvement in facial profile, and sixty-three percent of patients assessed that their profiles were improved more substantially than expected before treatment. As for facial parts, more than seventy percent of patients mainly recognized improvement in lower lip and chin.

3. The patient's recognition of improvement in facial profile, especially chin, exhibited a significantly positive correlation with the amount of mandibular setback during treatment.

These results suggested that most patients assessed that improvement in facial profile was achieved by orthognathic surgery. It is shown that their recognition of improvement in their facial profiles is significantly correlated with the amount of mandibular setback.
\end{abstract}

Key words : orthognathic surgery (顎矯正手術), questionnaire (質問紙法), facial profile (顔貌) [Received Nov. 30, 1995]

広島大学歯学部歯科矯正学講座（主任：丹根一夫教授）

Department of Orthodontics, Hiroshima University School of Dentistry (Chief : Prof. Kazuo TANNE) 


\section{緒言}

近年，顎矯正手術の進歩に伴い，顎変形症患者 の顔貌ならびに咬合の不調和を大きく改善するこ とが可能となった。このような治療による顎顔面 骨格の変化とこれに伴う顔貌の変化は，患者の心

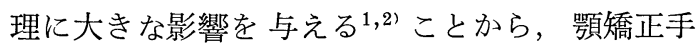
術による顔貌の変化を患者自身がどのように認識 しているかを正しく把握しておくことが重要であ る。

顎矯正手術の結果に関する患者の認識について, 山田 ${ }^{3-6)}$ は下顎前突患者を対象に 質問紙法調查を 行い, 顔面変形の高度な患者ほど術後に情緒不安 が減少し, 行動パターンが外向性へと変化する傾 向があるものの, 術前の顔面変形の程度と手術前 後の顔貌に対する自己評価に有意の関連性はなか ったと報告している。しかし，手術による顎顔面 形態や顔貌の変化の程度と, それに対する患者の 認識との関連性についての詳細な検討はなされて いない。

本研究では, 顎矯正手術を適用した下顎前突患 者に対する質問紙法調査により，手術による顔貌 の変化についての患者自身の認識を把握し, さら にこれらの結果と手術による顎顔面形態の変化と の関連性を明らかにすることを目的とした。

\section{資料および方法}

\section{I . 研究対象}

広島大学歯学部附属病院矯正科にて, 顎矯正手 術のための術前・術後矯正治療を受けた患者のら ち, 術後矯正治療が終了した患者 120 名に質問紙 を郵送した。回答を得た55名 (回答率46\%)のうち, 著しい開咬，顎偏位，および口唇裂口蓋裂などを 伴う患者を除いた下顎前突患者43名（男性13名, 女性30名）を研究対象とした。対象症例の手術時 年齢は平均 20 歳 9 力月 (14歳 3 力月 29歳0力月), 調査時年齢は平均 25 歳 5 力月（18歳 7 力月 34歳 6 力月）で, 手術後平均 4 年 8 力月（9 カ月〜 11 年 1 カ月）が経過していた。

質問紙の内容の一部を Table 1 に示す。質問 紙の回答に際しては,「はい，いいえ」の間を 7 段 階に分け，そのひとつを選ばせることにより患者
の認識の程度を評価した（Fig．1）。また，選択 肢を用意した質問では複数回答を許容した。さら に, 質問内容に応じて患者の意見を具体的に記入 する欄を用意した。

研究資料としては, 対象症例の初診時および治 療終了時における側面頭部X線規格写真を用いた。

II . 分析方法

1. 質問紙法調查の集計

各項目について回答の度数を算出するとともに， その割合を図示した。

\section{2. 側面頭部X線規格写真分析 (Fig. 2)}

下顎骨に関する項目として，1） $\angle \mathrm{SNB} 2 ） \angle$ ANB 3) $\angle \mathrm{SNPog}$ 4) Ans-Me 5) $\mathrm{Me}(\mathrm{X}) 6$ ) $\mathrm{Me}(\mathrm{Y})$ の 6 項目の初診時打よび治療終了時の值 と術前後の変化量を計測した。 $\mathrm{Me}$ については, フランクフルト平面をX軸とし，これに直交し $\mathrm{S}$ 点を通る直線を $\mathrm{Y}$ 軸とした基準座標系を設定し， その $\mathrm{X}, \mathrm{Y}$ 座標值である $\mathrm{Me}(\mathrm{X}), \mathrm{Me}(\mathrm{Y})$ を計 測した。なお， $\mathrm{Y}$ 軸より前方， $\mathrm{X}$ 軸より下方を正 の值とした。また，すべての計測值について，治 療後の值と初診時の值の差をその変化量とした。

3. 質問紙法調查集計結果と側面頭部 X線規格 写真分析結果との間の関連性の検討

質問紙法調査集計結果のうち，顔貌に関する項 目の調查結果と側面頭部X線規格写真分析結果と の間で, Spearman の順位相関分析を行った。分 析に際しては， 7 段階の質問紙法調査回答結果を カテゴリーデータとして用い，Fig. 1 に示す 7 段 階スケールの左側（はい，良い）から右側（以い え, 悪い）に向かって $1 ， 2 ， 3 \cdots$ と昇べき順に 番号を付与した。設定したカテゴリーデータと， 治療前後の頭部 X線規格写真分析結果およびその 変化量との間で相関の有無を検討した。

\section{結 果}

I . 質問紙法調查結果

1. 治療前の状態に関する結果

1）治療前の顔貌に対する認識

治療前の自分の顔貌が気になっていたかという 質問に対して，患者の $88 \%$ が「気になっていた」 と答え, そのうちの約半数は「非常に気になって いた」と回答していた。男女別にみると, 男性で 
Table 1 A list of questionnaires

1. When did you notice the disharmony of facial profile?

（自分の顔の形が気になり出したのはいつ頃からですか?）

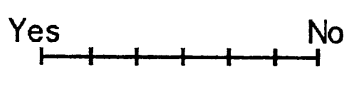

2. Did you expect the improvement in facial profile after treatment （治療前，自分の顔の形が気になっていましたか?）

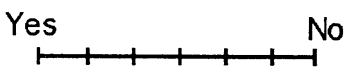

3. How much degree did you notice the disharmony of facialprofile before treatment?

（顔を正面と横から見て，どの部分がどの程度気になっていたか，答えて下さい。）

$\begin{array}{lc}\begin{array}{l}\text { frontal facial } \\ \text { profile }\end{array} & \text { midface } \\ & \text { mandibular gon } \\ & \text { lips } \\ & \text { chin } \\ & \text { others ( } \\ \text { lateral facial } & \text { nose } \\ \text { profile } & \text { upper lip } \\ & \text { lower lip } \\ & \text { chin } \\ & \text { others }\end{array}$

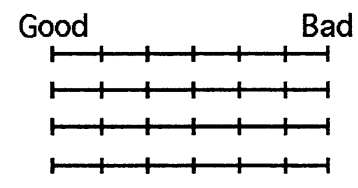

others

4. Did you expect the improvement in facial profile after treatment?

（治療前，手術を受けることによって，顔の形が良くなると期待していましたか?）

5. Do you notice the improvement in facial profile after treatment?

（治療を受けた後，自分の顔貌が良くなったと思いますか?）

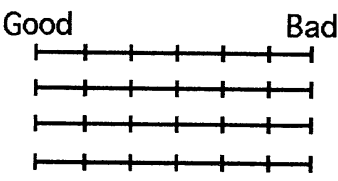

6. How much degree do you evaluate the improvement in facial profile after treatment?

（顔を正面と横から見て，どの部分がどの程度良くなったと思うか，答えて下さい。）

$\begin{array}{lc} & \text { midface } \\ \text { frontal facial } & \text { mandibular gonion } \\ \text { profile } & \text { lips } \\ & \text { chin } \\ & \text { others ( } \\ & \text { nose } \\ \text { lateral facial } & \text { upper lip } \\ \text { profile } & \text { lower lip } \\ & \text { chin } \\ & \text { others ( ) }\end{array}$
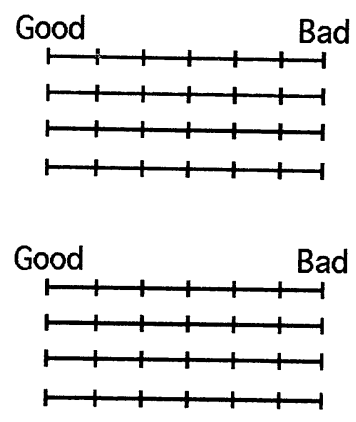

7. Do you recognize the improvement in facial profile more than expected before treatment?

（現在の顔の形は，治療前に期待していたよりも良くなりましたか?）

8. Do you think if your character has been changed after treatment?

（手術前と比べて，自分の性格が変わったと思いますか?）

How is the change? (multiple choice is available)

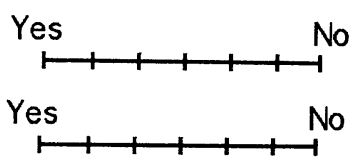

（性格が変わったと回答された方は，どのように変わったと思いますか？）

9. Do you want to keep your experience of the treatment secret from others? （手術をしたことを，人に知られたくないですか?）

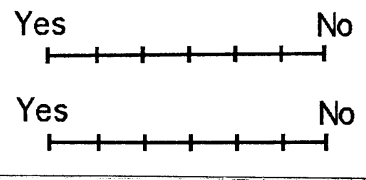




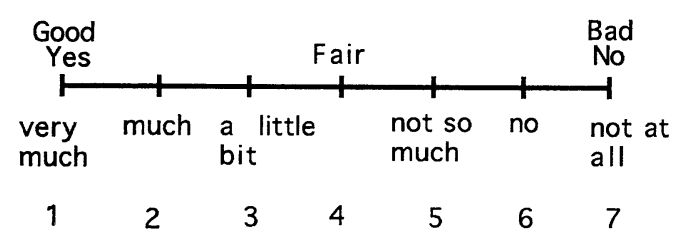

Fig. 1 Quantification of patient's recognition to be used as categories rangeing from 1 to 7

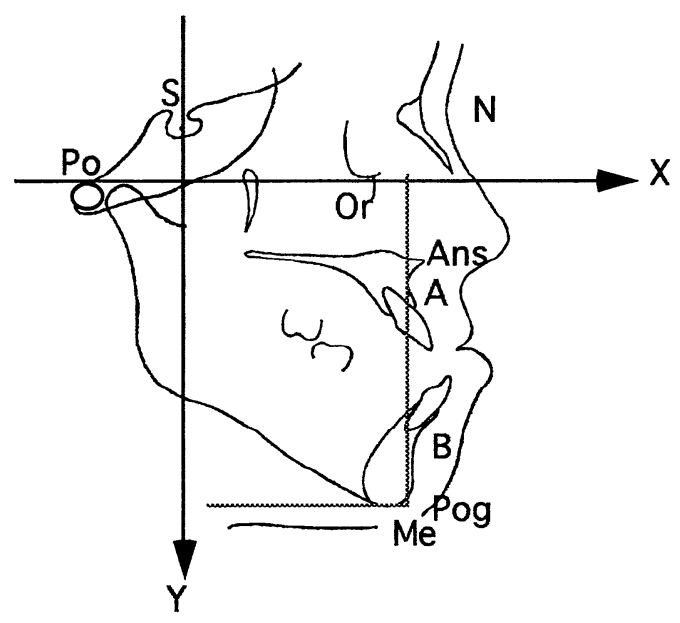

Fig. 2 X-Y coordinate system and landmarks for lateral cephalometric analysis

は13名全員が「気になっていた」と回答していた。 女性では「気になっていた」と回答したのが $83 \%$ (25名)で，「どちらともいえない」「気にならなか った」がそれぞれ14\%（4名)，3\%（1名）であ った（Fig. 3)。

自分の顔貌が気になり始めた時期は, 小学校高 学年, 高等学校時がともに $30 \%$ と最も多く, つい で中学校時が $19 \%$ となっていた。男女別にみると， 男性では高等学校時が $46 \%$ と最も多く, ついで中 学校時が $23 \%$ であった一方，女性では，小学校 高学年が $36 \%$ で最も多く, 男性よりもかなり早い 時期から顔貌の不調和を気にし始めていたことが 明らかとなった (Fig. 4)。

手術前の自分の顔貌を部位別に評価した結果を Fig. 5に示す。正貌に関して，「悪い」と回答し た患者の割合は，顔の中央部や下顎角部について はそれぞれ $28 \% ， 26 \%$ と少なかったのに対し，口 唇では65\%，オトガイ部では $65 \%$ と高い割合を示 した。具体的には,「顔が長く, 冷たい感じ」,「顔
の中で㖽の占める割合が大きい」，「下唇の下が膨 れている」,「顎が尖っている」,「顎が長い」,「唇 が薄い」などの回答があった。

また，側貌に関して，鼻と上唇部では,「どちら ともいえない」もしくは無回答が合わせて $60 \%$ 以 上と大きな割合を示した。一方，下唇とオトガイ 部では「悪い」と回答した患者はそれぞれ $86 \%$ ， $79 \%$ と, 非常に高い割合を示した。具体的には,

「顎が出ている」，「顎が長い」，「凹凸がなく平ら な顔の線」などの回答が見られた。

2) 手術に対する期待

手術によって顔貌が良くなると期待していたか という質問に対して，93\%の患者が「期待してい た」と回答した。男女別では，男性は全員が「期 待していた」と回答したのに対して，女性では87 \%が「期待していた」とし，「期待していなかっ た」としたものが13\%（3名）であった（Fig. 6)。 顔貌が良くなることを期待していなかった 3 名の うち，2名は治療前に顔貌の不調和を気にしてい なかった患者であった。残る 1 名は, 治療前に顔 貌の不調和を気にしていたものの,「顔が変わるこ とを，周囲の人がどう思らか不安である。美容整 形をしたと思われたくない。」と答えていた。

2. 治療後の状態に関する結果

1）治療後の顔貌に対する認識

治療後の顔貌が良くなったと思うかという質問 に対して，患者の $84 \%$ が「良くなった」と回答し ていた。男女別では，男性は全員が「良くなった」 と回答していたが，女性では「良くなった」が77 \%,「どちらともいえない」が20\%（6 名）であっ た（Fig. 7)。「どちらともいえない」と回答した 6 名のらち 4 名は, 治療前に自分の顔貌が「気に ならない」または「どちらともいえない」と回答 して抢り，治療による顔貌の変化を強くは希望し てなかった。残る 2 名は,「治療により顔貌が良く なったが，期待以下であった」，「期待以上に顔貌 が良くなったものの, 治療後の顔貌においても顔 が長い」と回答し，治療結果に十分満足していな いことが示された。

手術後の顔貌を部位別に評価した結果を Fig. 8 亿示す。正貌に関して, 顔の中央部や下顎角部 では「どちらともいえない」あるいは無回答とし 
Whole subjects

Male

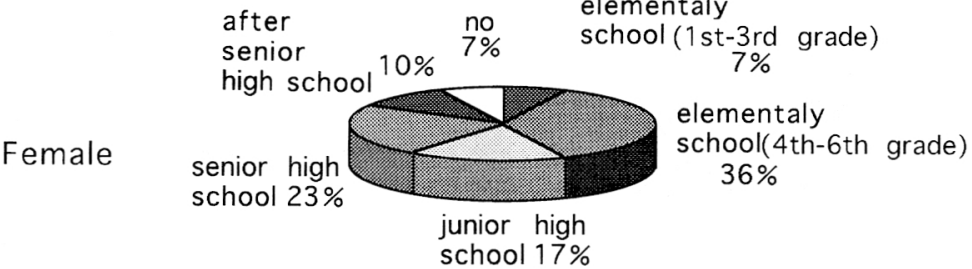

Fig. 3 When did you notice the disharmony of facial profile?

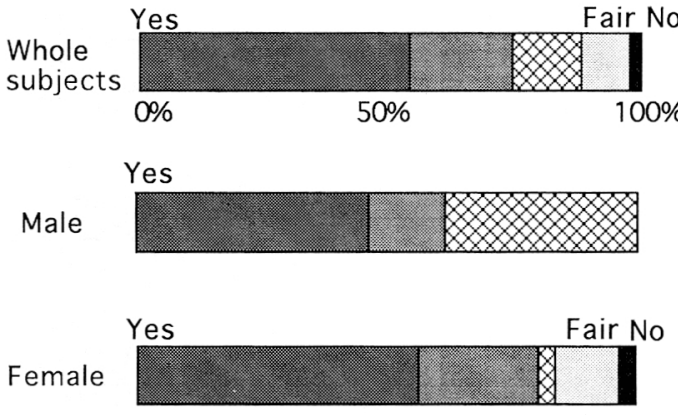

Fig. 4 Did you notice the disharmony of facial profile before treatment?

た患者の割合が，それぞれ $84 \% ， 65 \%$ と最も多か った。これに対して，口唇では $58 \%$ ，オトガイ部 では $63 \%$ が「良くなった」と回答して打り，顔貌 の改善を十分認識している患者の割合が高くなっ ていた。正貌の変化について，具体的には,「顔が 丸くなった」，「印象がやわらかくなった」，「唇の 形が良くなった」などの回答が見られた。

側貌に関しては，鼻と上唇部では「どちらとも いえない」もしくは無回答とした患者が，それぞ
れ $86 \% ， 72 \%$ と多く，改善の認識が低かった。一 方，下唇とオトガイ部では，「良くなった」と回答 した患者はそれぞれ $74 \% ， 72 \%$ で，かつ「非常に 良くなった」とした回答が多く見られた。側貌の 変化について，具体的には，「䫈がひっこんだ」， 「顎の線がきれいになった」,「上下唇のバランスが 良くなった」などの回答があった。

顔貌が治療前に期待していたよりも良くなった かという質問に対して，63\%の患者が「期待して いたよりも良くなった」と回答していた（Fig．

9 )。「期待していたより良くなかった」としたも のは約 $12 \%$ （5名）であった。また，治療後の顔 貌改善の認識（Fig. 7）をみると，期待以下であ った 5 名のうち 4 名は,「期待したよりは良くなか ったが特別不満はない」「良くなったのは確かだ が，完全には治らなかった」と，期待していたよ り良くないとしたものの,「手術により顔貌が良く なった」，「治療を受けて良かった」と回答してお

り，治療後に顔貌が「良くなった」と回答してい た。残る 1 名は, 治療前の顔貌についても, 顔貌 


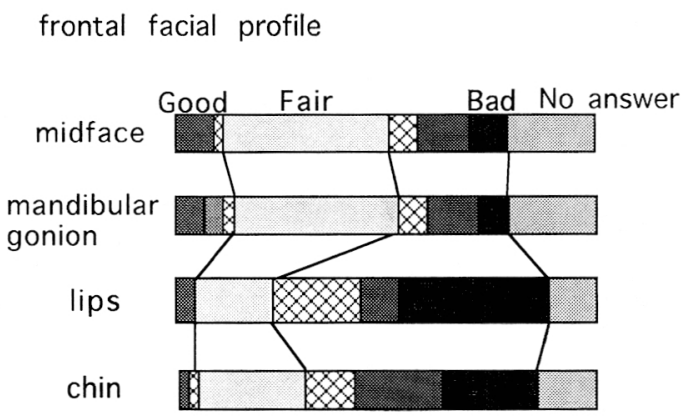

lateral facial profile

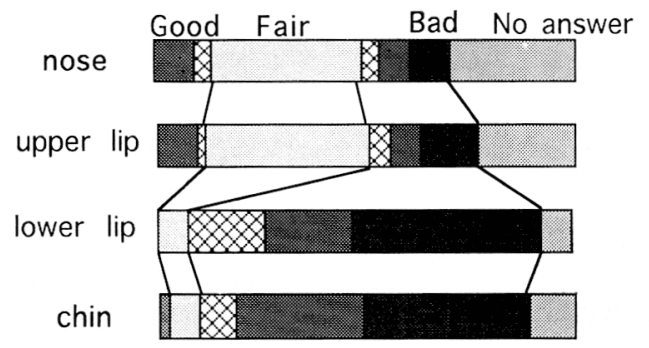

Fig. 5 How much degree did you notice the disharmony of facial profile before treatment?

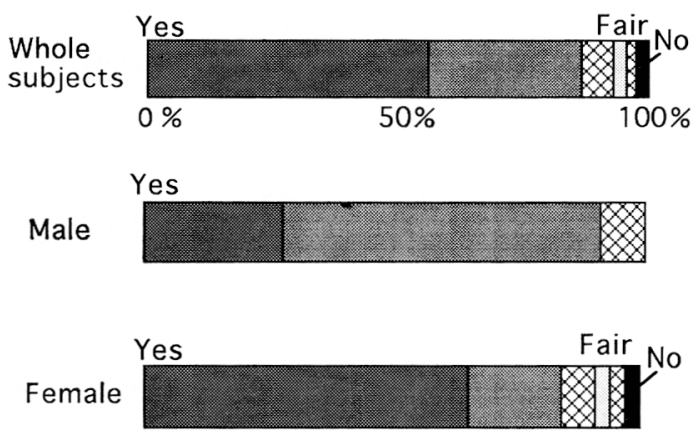

Fig. 6 Did you expect the improvement in facial profile after treatment?

の改善（Fig. 7) についても「どちらともいえな い」と回答しており，もともと顔貌の不調和を主 訴とはしておらず，顔貌の改善を希望していなか ったためと考えられる。一方，期待どおりまたは 期待以上に顔貌が改善したとしたものの, 治療後 の顔貌について「どちらともいえない」としたも のが 5 名見られた。

2) 手術後の心理状態

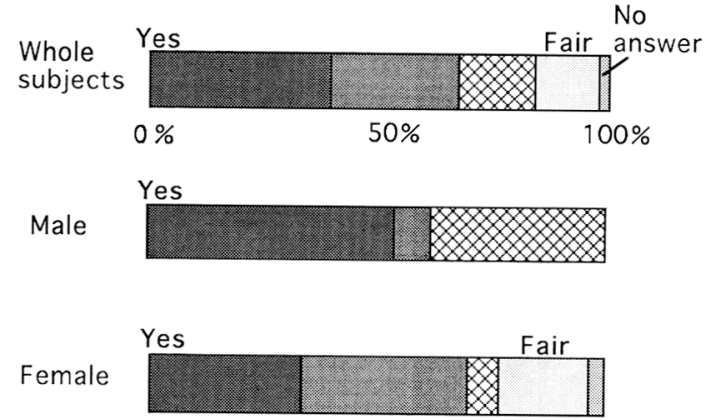

Fig. 7 Do you notice the improvement in facial profile after treatment?

frontal facial profile

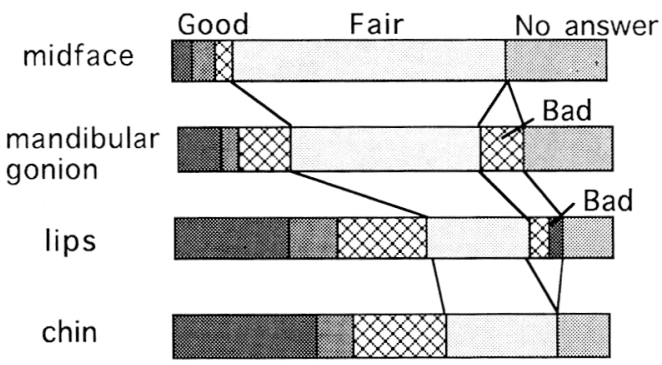

lateral facal profile

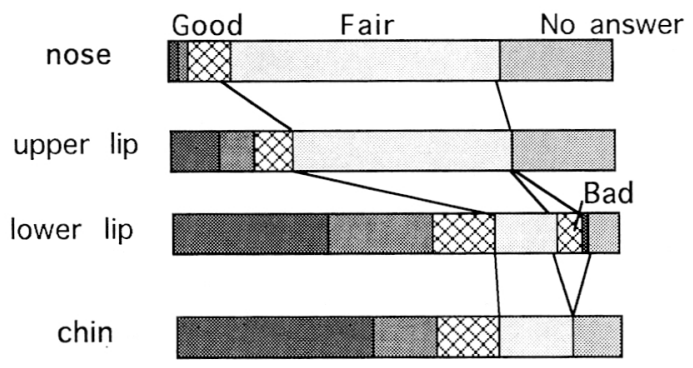

Fig. 8 How much degree do you evaluate the improvement in facial profile after treatment?

手術をしたことを他人に知られたくないかとい ら質問に対して,「知られたくない」と回答した患 者と、「知られても良い」と回答した患者は，いず れも44\%と同じ割合を示した（Fig. 10)。

手術前と比べて自分の性格が変わったと思うか といら質問に対して，51\%の患者が「変わった」 と回答していた。どのように変わったかという問 

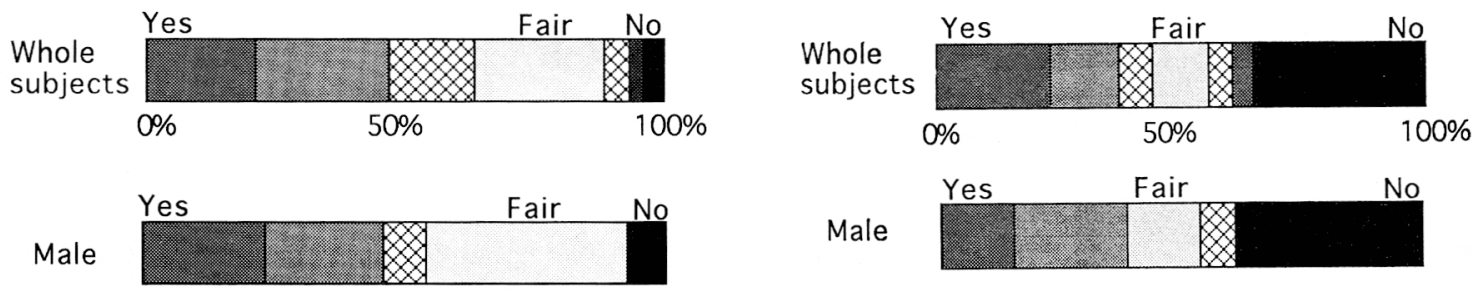

Male

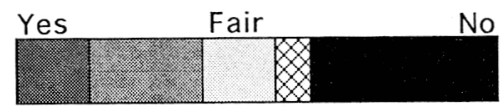

Yes

Female

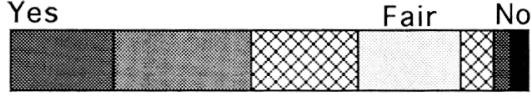

Fig. 9 Do you recognize the improvement in facial profile more than expected before treatment?

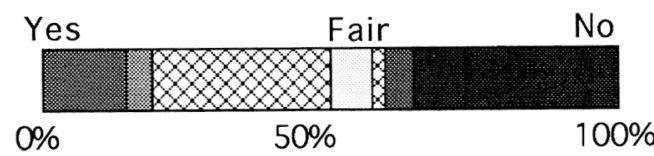

less self-conscious
more confident
more cheerful
more positive

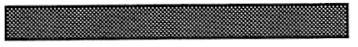

more self-confidence 0

less confident 0

$\begin{array}{ll}\text { more gloomy } & 0 \\ \text { more negative } & 0\end{array}$

miscellaneous $\quad 3$

The number in this diagram denote the number of subject

Fig. 11 Do you think if your character has been changed after treatment? How is the change? (muliple choice is available)

、には、「人前に出ても恥ずかしくなくなった」,

「自信がもてるようになった」「明るくなった」,

「積極的になった」など, 外向性の変化が挙げられ

て抢り，内向性の変化を挙げた患者はいなかった

(Fig. 11)。

3. 治療の総合評価

治療を受けて良かったという質問に対しては, 95\%の患者が「治療を受けて良かった」と回答し
ていた。残りの $5 \%$ （2名）は「どちらともいえ ない」としていた（Fig. 12）。この2名は，手術 の必要があることを知ったとき「仕方ない」,「不 安だった」と感じて抒り, 積極的に治療を希望し ていなかった。また, 治療全体について「想像し ていたよりもつらかった」と答えており，顔貌の 改善を認識していたものの総合評価が低かったも のと考えられる。 

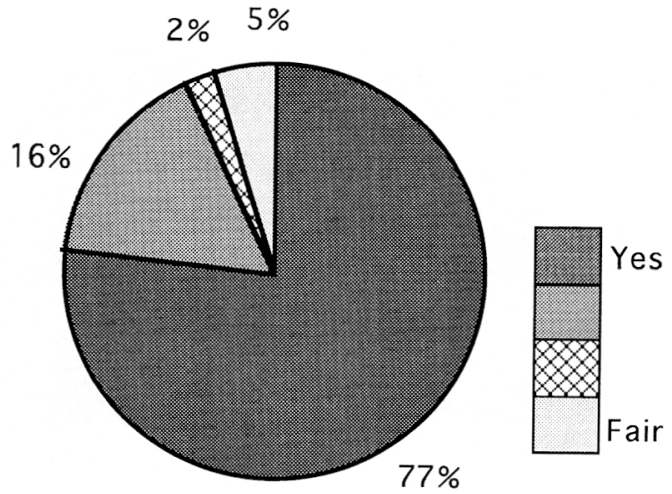

Fig. 12 Are you satisfied with the results of treatment?

II . 質問紙法調查結果と顎顔面形態の変化との 関連性

初診時と治療終了時の側面頭部 X線規格写真の 分析結果を Table 2 に示す。初診時と最終観察 時を比較すると, Me は後上方への位置変化を示 し, その変化量沙後方一平均 $9.2 \mathrm{~mm}$, 上方一平均 $1.4 \mathrm{~mm}$ であった。その結果, $\angle \mathrm{ANB}$ は平均一 5.0 度からー0.6度へと改善された。

質問紙法調査の集計結果と側面頭部 X 線規格写 真分析結果の関連性について, Spearman の順位 相関分析の結果を Table 3 に示す。

顔貌が気になり始めた時期や顔貌が気になって いた程度と，初診時の顎顔面形態の不調和の程度 との間に相関は見られなかった。

治療後に自分の顔貌が良くなったと思うか，と いら設問に対する回答と $\mathrm{Me}(\mathrm{X})$ おょび $\angle \mathrm{SNPog}$ の変化量との間に有意の正の相関が， $\mathrm{Me}(\mathrm{Y})$ と Ans-Me の変化量との間に有意の負の相関が明 らかとなった。また，治療後の側貌におけるオ卜 ガイ部の位置に関する 自己評価結果は, $\mathrm{Me}(\mathrm{X})$
の変化量との間に有意の正の相関, $\mathrm{Me}(\mathrm{Y})$ の変 化量と術後の $\angle \mathrm{ANB}$ との間に有意の負の相関を 示した。さらに，側貌におけるオトガイ部の改善 の認識に対する回答は, $\mathrm{Me}(\mathrm{X})$ の変化量との間 に有意の正の相関， $\mathrm{Me}(\mathrm{Y})$ の変化量との間に有 意の負の相関を示した。特に, 治療後の顔貌が改 善されたという認識, および治療後の側貌におけ るオトガイ部の評価については，いずれも $\mathrm{Me}$ （X）の変化量と強い正の相関を示し，オトガイ部 が後下方に移動したものほど改善を認識していた。 なお，Fig. 13に示すように $\mathrm{Me}(\mathrm{X})$ と $\mathrm{Me}(\mathrm{Y})$ の間には強い負の相関が示された。

\section{考察}

\section{I . 調査方法について}

䫟顔面骨格の変形とこれによる顔貌の不調和や， 治療後の顔貌の変化が患者の心理に大きく影響し ているような場合，面接方式では顔貌に対する認 識や心理面での変化などに関して，患者によって は正直な回答が得られないことも考えられる。こ のため, 本研究では患者が質問者を意識すること なく, 面接方式に比べより正直な回答が得られる と考え，郵送による質問紙法を用いた。この方法 では質問内容に対する疑問や䛊解が生じる可能性 があるが，これを防止するため回答方法について は具体例を示し，顔貌についての質問には図を添 付した。また，より詳細な患者の意見を得るため に自由記入欄を設けた。

また，手術による顎顔面形態の変化と患者の認 識との関連性を検討するため, 回答を 7 段階の力 テゴリーデータに変換した。このような数量化に より，質問紙法調査結果のような質的データと数 量データの関係を分析することが可能となり, 異

Table 2 Means and standerd deviations of cephalometric measurement

\begin{tabular}{lrrr}
\hline & before treatment & after treatment & changes during treatment \\
\hline$\angle \mathrm{SNB}\left(^{\circ}\right)$ & $84.6 \pm 4.1$ & $80.5 \pm 4.5$ & $-4.0 \pm 2.0$ \\
$\angle \mathrm{ANB}\left(^{\circ}\right)$ & $-5.0 \pm 3.2$ & $-0.6 \pm 2.8$ & $4.4 \pm 2.4$ \\
$\angle \mathrm{SNPog}\left(^{\circ}\right)$ & $84.6 \pm 4.4$ & $80.6 \pm 4.7$ & $-4.0 \pm 2.3$ \\
$\angle \mathrm{Ans}-\mathrm{Me}(\mathrm{mm})$ & $78.7 \pm 6.8$ & $78.0 \pm 6.1$ & $-0.7 \pm 2.8$ \\
$\angle \mathrm{Me}(\mathrm{X})(\mathrm{mm})$ & $63.8 \pm 9.6$ & $54.7 \pm 8.6$ & $-9.2 \pm 4.4$ \\
$\angle \mathrm{Me}(\mathrm{Y})(\mathrm{mm})$ & $110.0 \pm 9.1$ & $108.6 \pm 8.1$ & $-1.4 \pm 2.5$ \\
\hline
\end{tabular}




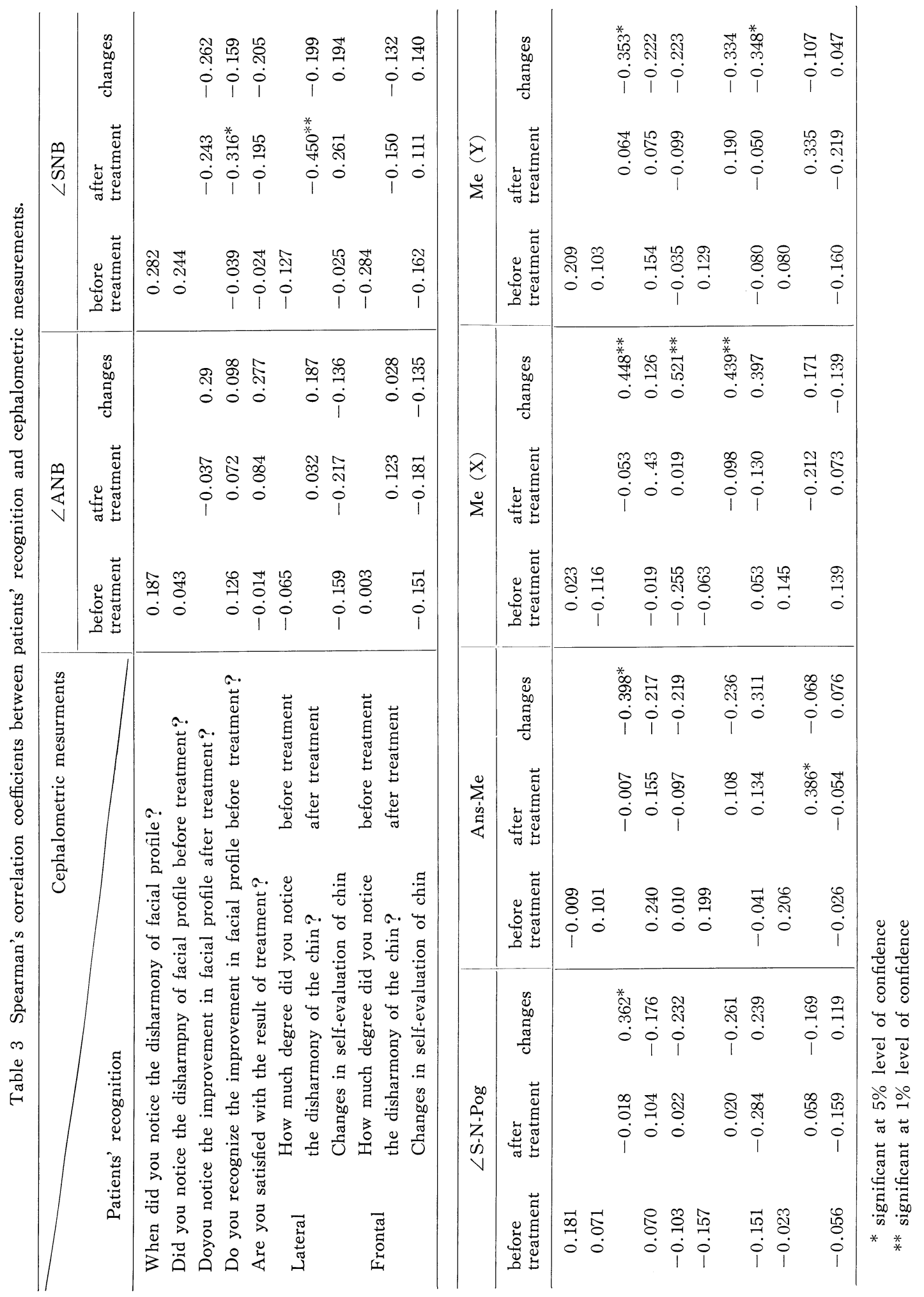




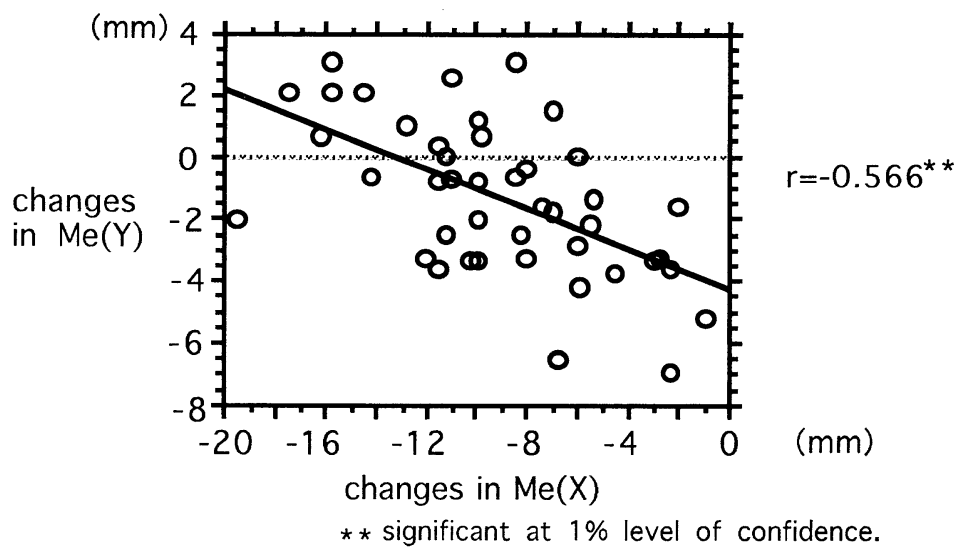

Fig. 13 Correlation between changes in $\mathrm{Me}(\mathrm{X})$ and $\mathrm{Me}(\mathrm{Y})$ during treatment

質なデータを用いた解析には有効な手法と考えら れる。

II . 質問紙法調査集計結果について

1. 術前の状態に関する意識について

従来, 下䫟前突患者は機能面のみならず審美面, 心理面においても大きな影響を受けていることが 報告されている ${ }^{15)}$ 。今回の質問紙法調査結果にお いても，治療前の自分の顔貌が気になっていたも のは全体の約 $90 \%$ ときわめて高い割合を占めてい た。また，非常に気にしていたと答えたものも全 体の約半数であった。多くの患者が，治療前に 「人前では口元を隠していた」，「顔や口元につい て他人から気になることを言われた」などと答え ていることからも，患者の大半が顔貌の不調和に 起因する強い劣等感を有していたことが示された。 さらに，患者の大半が，手術を受けることによっ て顔貌が良くなると期待していたことからも，患 者が機能面の改善のみならず審美的障害を自覚し, その改善を強く望んでいたことが示された。顔貌 の不調和が気にならなかった」または「どちらと もいえない」と回答した 5 名は，主として咬合の 改善を希望していた。

従来, 男性と比べて女性の方が醜形により強い 関心を持ち，その改善を望んでいると考えられて いた。今回の結果においては, 顔貌が気になり始 めた時期が男性に比較し女性が早い傾向にあった ものの，審美障害および審美面の改善を強く望ん でいるものの割合は，むしろ男性が高い結果とな
った。その理由として，最近の社会環境の変化に より男女の美的要求の差が不明瞭になってきたこ とが考えられる。また，今回対象とした患者数に 男女差があるため, 結論を出すには更なる検討が 必要であろう。

山田 ${ }^{3-6)}$ が，顎矯正治療を適用した下顎前突患 者を対象として行った質問紙法調査によると，下 顎前突患者は術前, 術後ともに口唇部を中心とし た側貌，正貌に最も関心を持っているとされてい る。本研究においても, 顔貌の部位別の評価では, 口唇部およびオトガイ部に対する関心が高いとい ら結果が得られたことから，下顎前突症の外科的 矯正治療に際しては，この部位の改善が図られる ような下顔面部の十分な後方移動のための計画を 立案する必要がある。

2. 術後の状態に関する意識について

治療後の顔貌の変化について, 橋本ら ${ }^{8,9}$ は, オ トガイ部の突出感が取れたという回答が最も多か ったと述べている。本研究に执いても，正貌では 患者の約 $60 \%$ が口唇とオトガイ部の改善を, 側貌 では患者の $70 \%$ 以上が唇とオトガイ部の改善を 挙げていた。さらに，側貌においては，非常に良 くなったとしたものが多く，側貌における下唇と オトガイ部への関心がより高く, 改善の認識も高 いと考えられる。伊藤ら ${ }^{7}$ は，外科的矯正治療を 適用した骨格性下顎前突患者に質問紙検查および $\mathrm{Y}-\mathrm{G}$ 検查を行い，男子では対社会的な審美性や 機能のこだわりの改善が主であり，女子では自己 
内面的こだわりの改善と情緒安定性の向上による パーソナリティ変化が主であり外科矯正治療の心 理学的影響には性差がある, と報告している。

本研究は質問紙法検查のみであるため, 詳細な 検討は困難であるが，以下のような傾向が認めら れた。すなわち治療後の状態については, 女性よ り男性で「治療後, 自分の顔貌が良くなった」と 回答したものが多かった。しかし，期待したより も良くなったと回答したのはむしろ女性に多かっ たことから，女性は顔貌の改善を十分認識してい るものの, 顔貌の不調和が解消した時点で美的要 求がより高いレベルへ変化したものと思われる。

手術をしたことを人に知られたくないかという 質問に対しては，「知られたくない」，「知られて も良い」といら回答がほぼ同じ割合で認められた。 この結果に性差はなく, 術前後の顎顔面形態との 間に関連性が認められなかったことから，患者の もともとの劣等意識や性格に起因した結果と考元 られる。知られたくないとしたものの中に, 他人 に美容整形をしたと思われる不安を挙げたものが 数名みられた。現在では美容整形がかなり一般的 になってきつつあるが,「醜さは病気ではない」と いった風潮や，親にもらった体にメスを入れるこ とへの非難などいまだ偏見も多い。そのため, 今 までの劣等意識と相まって,「治療による顔貌の変 化を他人がどのように受けとめるか」という新た な不安を有する場合があることを理解すべきであ る。

また, 手術後の性格については, 半数が変わっ たと回答し，その全てが外向性への変化であった。 Crowell ら ${ }^{16)}$ や Hutton ${ }^{17)}$ の調查によると, 外 科的矯正治療適用患者の半数以上が性格の変化を 認め, そのほとんどが内向性の性格の改善であっ た。また, 橋本 ${ }^{8,9)}$ は, 顎変形症患者の術後の性 格について, 変形に由来する劣等感が少なくなっ たことを反映している，と述べている。本研究の 結果からも，下顎前突に起因する審美障害や機能 障害, さらに心理的障害が治療によって取り除か れた患者が多かったものと考えられる。

なお, 患者の手術時年齢, 回答時年齢, 手術後 経過時期の違いにより意識に差異が生じる可能性 が考えられる。そこで，結果には示さなかったが，
術後の状態に関する意識についての集計結果との 間の相関の有無を検討したところ有意な相関は認 められなかった。したがって, 手術時年齢, 回答 時年齢，手術後経過期間の違いによる意識の差異 はないと考えられる。

III. 顔貌の評価と顎顔面部の形態変化との関連 性について

顔貌の不調和が気になりだした時期や，その程 度と, 治療前の側面頭部 X線規格写真計測值との 間に有意の相関は見られなかった。山田 ${ }^{3-6)}$ や難 波ら $^{1,2}$ は, 変形が高度であるからといって, 患者 の行動パターンにまで悪影響を及ぼすものではな く, 㪕度の変形の者でも強く不安を訴える者も認 められた，と報告している。また，土川ら ${ }^{10)}$ は， 顔かたち, 容姿全体にかかわる cathexis は不正 の程度よりむしろ発育段階と関係し, 学齢の増加 に伴い cathexis は増大し, その増加率は青年前 期から中期に著しくなる，と述べている。これら の所見から，顔貌の評価は非常に主観的であり， 顔貌の不調和を気にし始めた時期やその程度は個 々の患者の性格により異なるものと考えられた。

治療による顔貌の改善, とりわけオトガイ部の 改善に対する認識は下顎骨の後方移動量と強い関 連性を有し，後方移動量の大きいものほど顔貌の 改善を認識しており，治療の総合評価が高くなる ことが明らかとなった。また，オトガイ部の前後 的変化量と上下的変化量との間には負の相関が見 られたが，前後的変化量の方が大きいことから， 顔貌の変化にはオトガイ部の後方移動量が大きく 影響していると推察された。

治療に対する総合評価については，43名中41名 が治療を受けて良かったと回答していた。治療を 受けて良かったか，といら設問に対する回答と下 顎骨の後方移動量の間にも有意の相関関係が認め られたことから，下顎骨の後方移動量が大きいも のほど治療に対する総合評価も高くなることが明 らかとなった。評価が低かったものの中に「せっ かく治療したのだから，もっと下顎を後ろに下げ て欲しかった」と回答した患者が見られた。下顎 骨の後方移動量は治療前の顎顔面形態や咬合状態 などを考慮して，審美面および機能面の調和のと れた治療目標を設定することにより決定されるも 
のである。したがって，治療方針の選択に際して は, 下顎骨の後方移動量やこれに伴う顔貌の変化 を含めた十分な説明を行い患者の理解を得ておく ことが重要である。すなわち，外科的矯正治療の 治療方針の立案に際しては，患者の十分な理解を 得た上での治療方針の選択が必要であり，それに よって患者にとってより満足のいく治療結果を獲 得できるものと考えられる。

\section{文献}

1）難波雄哉，岡崎 博，鳥越雄喜 : みにくさの心理と 形成外科的治療との関係，(その 1 )醜形の精神健康 に及ぼす影響，補遺. 形成外科，6：263-269，1963.

2）難波雄哉, 岡崎 博, 鳥越雄喜 : みにくさの心理と 形成外科的治療との関係，(その 2 )醜形による性格 偏向にたいする形成手術の効果. 形成外科, $7: 171$ -175, 1964.

3）山田長信：下顎前突症患者の心理学的行動パターン に関する研究一アンケート調查による一第 1 編, 術 前, 術後自己評価の変化について. 日口外誌, 28 : 562-570, 1982.

4) 山田長信 : 下顎前突症患者の心理学的行動パターン に関する研究一アンケート調査による一第 2 編, 1 . 顔貌の程度と術前, 術後自己評価との関連性, 2. 顔 貌および咬合に関する患者評価と術者評価の相違. 日口外誌, $28: 571-583,1982$.

5）山田長信：下顎前突症患者の心理学的行動パターン に関する研究一アンケート調查による一第 3 編, 手 術に関する患者の総合評価について，日口外誌, 28： 584-597, 1982.

6）山田長信：下顎前突症患者の心理学的行動パターン に関する研究一アンケート調査による一第 4 編, ア ンケート調査項目の因子分析. 日口外誌， $28: 598-$ 603, 1982 .

7）伊藤智恵, 山影章子, 遠藤康子, 他 : 䫟矯正外科治
療の男女間における心理的影響の差異に関する研究 日矯歯誌, $47: 601-611,1988$.

8）橋本賢二，塩田重利，吉増秀實，他：顎変形症の手 術成績の検討. 第 1 報一術後アンケート 調 查から (その1)一. 日口外誌，35:171-184，1986.

9）橋本賢二，塩厌重利，吉増秀實，他：䪽変形症の手 術成績の検討・第 2 報一術後アンケート調査から (その2)一. 日口外誌, 35: 185-195, 1986.

10）土川登志子, 浅野央男, 大山正博, 他 : 不正咬合に 関わる cathexis について. 日矯歯誌, $41: 343-354$, 1982.

11）高口真奈美, 井藤一江, 山部耕一郎, 他 : 矯正治療 結果に対する患者・保護者の意識について. 日矯歯 誌，49：454-465， 1984.

12）花岡 宏，松田哲明，上村健太郎，他：骨格性反対 咬合における外科矯正の治療目標. 日矯歯誌，43: 289-324，1984.

13）伊藤 真，熊澤康雄，柿崎真一，他：顎変形症にお ける心理的変化一アンケート調査の術前・術後比較 一. 顎変形研究会会誌, $7: 96-97,1988$.

14）大原久子，寺田員人，篠倉 均，他：アンケート調 查による外科矯正治療後の患者の心理について. 顎 変形誌, $2: 32-47,1992$.

15) Macgregor, F. C. : Social and psychological implications of dentofacial disfigurement. Angle Orthod $40: 231-233,1970$.

16) Crowell, N. T., Sazima, H. J., Elder, S. T. : Survey of patients' attitudes after surgical correction of prognathism : study of 33 patients. J Oral Surg $28: 818-822,1970$.

17) Hutton, C. E. : Patients' evaluation of surgical correction of prognathism : survey of 32 patients. J Oral Surg $25: 225-228,1967$.

18) Peterson, L. J., Topazian, R. G. : Psychological considerations in corrective maxillary and midfacial surgery. J Oral Surg 34 : 157-164, 1976. 